
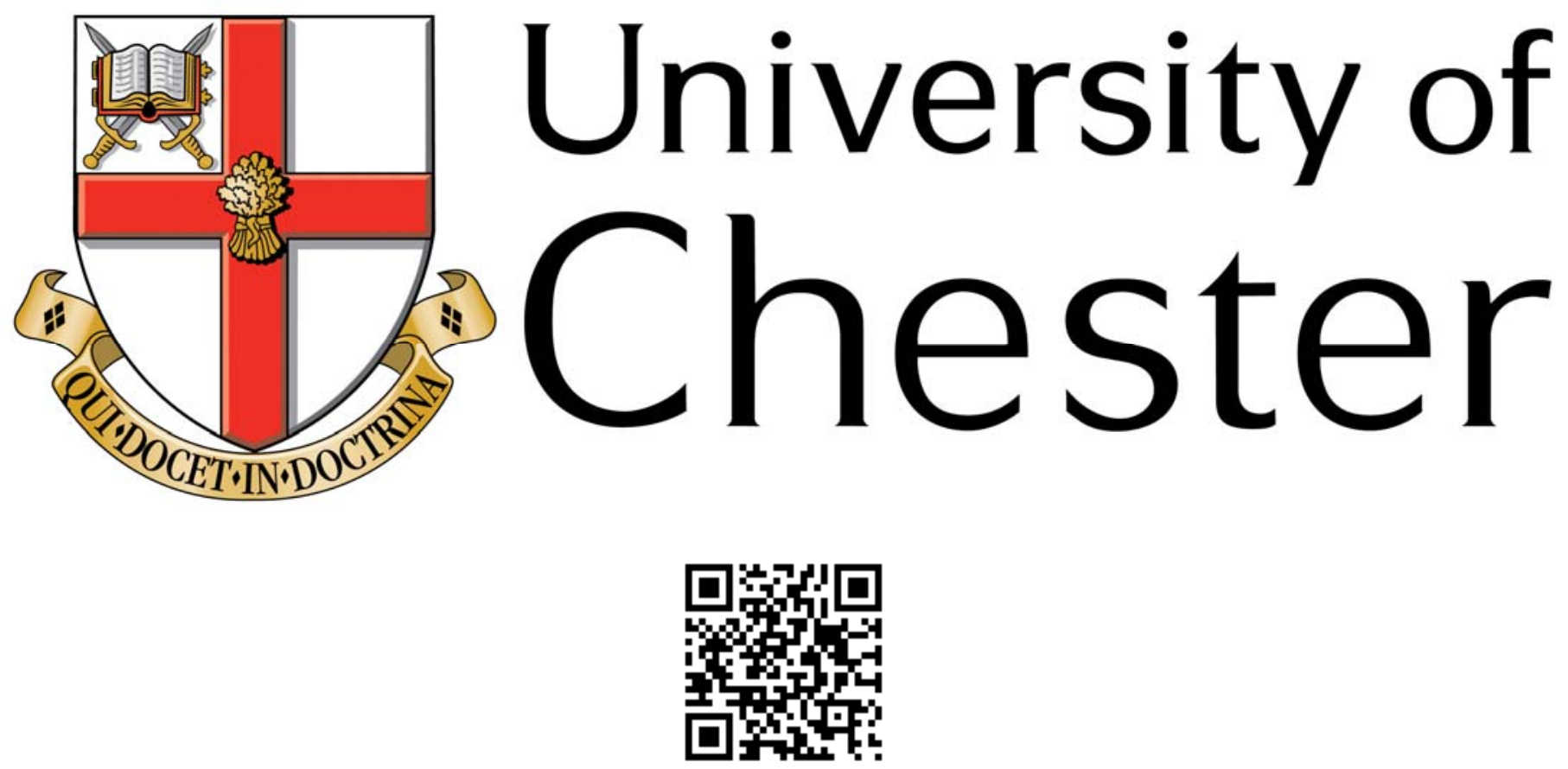

This work has been submitted to ChesterRep - the University of Chester's online research repository

\title{
http://chesterrep.openrepository.com
}

Author(s): Sarah Griffiths

Title: Businessmen and benefactors: The Macclesfield silk manufacturers and their support for the town's charitable institutions, 1750-1900

Date: 2008

Originally published in: Transactions of the Historic Society of Lancashire and Cheshire

Example citation: Griffiths, S. (2008). Businessmen and benefactors: The Macclesfield silk manufacturers and their support for the town's charitable institutions, 1750-1900. Transactions of the Historic Society of Lancashire and Cheshire, 157, 67-92.

Version of item: Author's post-print 


\section{Businessmen and benefactors: The Macclesfield silk manufacturers and their support for the town's charitable institutions, 1750-1900}

\section{Sarah Griffiths}

...perhaps no man was more generally respected, alike for his consistent geniality of temperament and his unpretentious generosity to the deserving poor and to all our charitable and other public institutions. ${ }^{1}$

This description of a leading Macclesfield silk manufacturer illustrates how members of this occupational group contributed towards the development of voluntary organisations as part of their public role. The following article will give a brief overview of their support, using the examples of Sunderland Street Wesleyan chapel and the ragged and industrial school, to show the ways in which they were influential. It will then explore the general reasons behind their charitable involvement and conclusions will be drawn about the extent to which their contribution was critical to the success of these Macclesfield institutions. The timescale used is 1750 to 1900 because this was when the silk industry was dominant in Macclesfield and the period in which most of the major institutions were founded.

The Industrial Revolution brought many changes to the charitable arena, especially the need to address the problems caused by rapid urbanisation and the part that industrialists played in the founding, management and support of new charities. Local philanthropic initiatives often provided the first steps towards establishing permanent institutions for the growing population. Some businessmen opted to provide their own complete range of facilities in factory villages, but the charitable efforts of most industrialists took place within towns or cities. Early manufacturers who established their own self-contained communities included the cotton manufacturers Robert Owen at New Lanark and Samuel Greg at Styal. They wanted to attract workers for their factories, which were often established in relatively remote areas, by offering superior accommodation and facilities. Other entrepreneurs whose operations were based in existing settlements could channel their contributions towards improvements for all inhabitants. As a result, the direct benefits of such actions for their workforces were reduced somewhat, particularly in comparison to the controlled

\footnotetext{
${ }^{1}$ Obituary of Thomas Unett Brocklehurst, Macclesfield Courier and Herald, 21 August 1886, p. 5.
} 
environment of factory villages. This is illustrated by the Strutt hosiery and cotton family who provided Derby with facilities, such as the arboretum and an art gallery/museum, which were accessible to all inhabitants and visitors. ${ }^{2}$

The textile belt of Lancashire and West Yorkshire was able to benefit from the many entrepreneurs who made handsome profits from their trade and the high degree of importance that they attached to charitable effort. ${ }^{3}$ For example, Henry William Ripley, Titus Salt (in addition to his efforts at Saltaire) and John Rand were amongst a group of prominent Bradford manufacturers who assigned a generous proportion of their considerable wealth to most of the local causes. ${ }^{4}$ Similarly, the silk town of Macclesfield had a number of successful businessmen who might be expected to support voluntary institutions in the town. The next section will look at this group of silk manufacturers in more detail.

\section{The Macclesfield silk manufacturers}

Macclesfield had always acted as a market town for east Cheshire but, following the establishment of the first silk mill in 1743, it industrialised to become the primary English centre for the manufacture of silk. This is illustrated by the fact that there were 169 silk companies operating in 1850, marking the high point of the industry's dominance in Macclesfield. ${ }^{5}$ The silk manufacturers themselves were a varied group of people and while some were heavily involved in town affairs, others remained anonymous. Their companies ranged from those with a few employees up to thousands and included those specialising in one area of silk manufacture (such as silk dyeing) or the whole range. These entrepreneurs did have some common characteristics such as expertise in the industry, technical awareness and access to capital and many were nonconformists. However, they all faced many obstacles to business success as silk was a luxury item and susceptible to any downturn in the economy. Similarly, foreign competition always threatened the success of the English silk industry and these factors meant that bankruptcies were common.

The most prominent silk manufacturing dynasty during this period was the Brocklehurst family, who took over an existing silk button business in the eighteenth century. Their venture expanded to cover all processes of silk manufacture and became the leading Macclesfield silk company in the nineteenth century, employing around 8,000 people

\footnotetext{
${ }^{2}$ R.S. Fitton and A.P. Wadsworth, The Strutts and the Arkwrights, 1758-1830: A study of the early factory system (Manchester, 1958), p. 187.

${ }^{3}$ A. Howe, The cotton masters, 1830-1860 (Oxford, 1984), p. 271.

4 J. Reynolds, The great paternalist: Titus Salt and the growth of nineteenth-century Bradford (Bradford, 1983), p. 75.

${ }^{5}$ S. Bagshaw, History, gazetteer and directory of the county palatine of Chester (Sheffield, 1850), pp. 244-45.
} 
at its height. Successive family members (most of whom were Unitarian in faith) were involved in the business until the early twentieth century and they were able to make significant profits from their efforts. ${ }^{6}$ For example, John Brocklehurst left assets worth $£ 800,000$ to his heirs in $1870 .^{7}$ Over a shorter timespan, the predominantly Methodist Ryle family ran the town's most successful silk business in the early nineteenth century, until the failure of the family bank in the 1840s resulted in the loss of their fortune. ${ }^{8}$

Apart from these two leading silk families, the other manufacturers came from a mixture of backgrounds, ranging from those who worked their way up from lowly positions to others whose existing wealth allowed them to exploit the business opportunities in the town. For example, Joshua Oldfield Nicholson (a Congregationalist from Leek) was apprenticed to a Macclesfield silk firm in 1855 and set up his own successful business ten years later, while John Walter Hook Thorp (an Anglican from Macclesfield) was able to join the family firm founded by his Quaker grandfather. ${ }^{9}$

These examples show that there were a number of Macclesfield silk manufacturers who amassed great wealth from their enterprises, despite the difficulties associated with the industry. This success meant that they were able to form a large section of the town's ruling elite and had considerable scope for involvement with the town's charitable institutions. There is little personal correspondence available on the silk manufacturers' philanthropic activities in Macclesfield and so institutional records provide the majority of the primary source material for this study. As many of the annual reports were designed to attract supporters, their focus on the positive aspects of each institution should be considered throughout this article. With these provisos in mind, we will now move on to explore Macclesfield's voluntary institutions.

\section{The voluntary institutions}

The 78 Macclesfield institutions that were founded with voluntary funding in this period fell into four broad categories — religion, education, public services and public amenities. The religious institutions included 61 churches, chapels, Sunday schools, day schools and missions. This high number was generally due to the separation of various sects which resulted in a complete set of new organisations. Macclesfield's population always had a

\footnotetext{
${ }^{6}$ C.S. Davies, A history of Macclesfield (Manchester, 1961), p. 136; J. Bray, The lady of Sudeley (Ebrington, 2000), p. 8.

${ }^{7}$ Chester and Cheshire Archives, MF 91/15, will of John Brocklehurst (1870).

${ }^{8}$ British parliamentary papers, First and second reports from the select committee on the petitions of ribbon weavers with minutes of evidence, 1818 (Shannon, 1968), p. 63.

${ }^{9}$ Macclesfield Courier and Herald, 15 March 1919, p. 3; J. Earles, Streets and houses of old Macclesfield (Macclesfield, 1915), p. 63.
} 
strong nonconformist element and this is shown by the 1851 ecclesiastical census which recorded that the seven Anglican churches provided $46 \%$ of the accommodation, compared to the nonconformists' 20 places of worship with 53\%. ${ }^{10}$ Sunday schools in Macclesfield followed the same pattern, being dominated by the Methodists, while the Anglicans took the lead in day schooling.

The secular education institutions included the grammar school and the girls' high school which catered for middle-class children in this period. The other organisations were designed to widen access to learning, particularly for adults who had received little formal education, and included the useful knowledge society, school of art and public library. The manufacturers hoped that such foundations would lead to an improvement in the town's silk products and it was no coincidence that many of them were heavily involved with these causes.

The public service institutions consisted of a range of initiatives aimed at improving the welfare of Macclesfield's inhabitants, such as the baths and dispensary. The foundation of such local facilities, alongside state-driven initiatives, meant that the nineteenth century saw a gradual improvement in the health of citizens. The public amenities consisted of the two parks, West Park museum and the volunteer drill hall. These were intended to provide suitable recreational activities for working people and to reduce the incidence of public disorder.

Four of Macclesfield's voluntary institutions were in existence by 1750, namely the grammar school, St Michael's church, the Mill Street meeting house and King Edward Street chapel. The second half of the eighteenth century saw the foundation of some key establishments, such as the large Macclesfield Sunday school, but it was in the nineteenth century that the greatest rise took place. There was a noticeable increase in nonconformist institutions in the early nineteenth century and then a rapid rise in the number of foundations (14) in the 1840s, primarily because of the concerted Anglican effort to regain ground lost to the nonconformists in previous years.

Certain Macclesfield institutions were direct donations from silk manufacturers and the Brocklehurst family gave the fence hospital, fence almshouses, Victoria Park and West Park museum, all in the latter half of the nineteenth century. These private donations contrasted with earlier initiatives which were primarily founded through fundraising efforts by the whole town. The largest single donation to a charitable institution in the period was

\footnotetext{
${ }^{10}$ Macclesfield Courier and Herald, 14 December 1872, p. 5.
} 
Joseph Tunnicliffe's $£ 30,000$ for the infirmary in 1859. At the other end of the scale, the silk manufacturers had little involvement with the Catholic and Primitive Methodist institutions which gained most of their funding from within the denomination. Therefore, Macclesfield's voluntary organisations operated in virtually all areas of town life at this time. There were some outright gifts of facilities from silk manufacturers, but the majority of institutions relied on town-wide appeals for funds and supporters. In order to see some of the different ways in which the silk manufacturers became involved, the following two examples, Sunderland Street Wesleyan chapel and the ragged and industrial school, will give an insight into the development of such establishments.

\section{Sunderland Street chapel}

Sunderland Street chapel was built in 1779 to provide the first permanent place of worship for Methodists in the Macclesfield area. It fostered a number of new institutions in the nineteenth century and managed to maintain its position as one of the town's main religious establishments until the mid-twentieth century.

The evangelical movement within the Church of England, which led to Methodism, became active in Cheshire in the 1740s. John Wesley preached in Knutsford in 1738 and the county became a regular fixture on his itinerary from $1745 .^{11}$ This movement, led by Wesley and George Whitefield, aimed to spread the message of the gospel through itinerant preachers and open-air meetings. Large numbers of people with little previous interest in religion were attracted to Methodism through the enthusiasm of the preachers and its relatively simple doctrine. Stockport gained its own purpose-built chapel in 1759, followed by Chester in 1765. Having been part of the York, Cheshire and then Chester circuit, Macclesfield gained its own circuit in 1770, which included Leek, Congleton and Stafford. In 1783, this had 1,380 members, showing the appeal of Methodism to inhabitants of

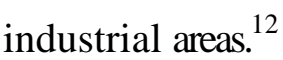

The early visits of Wesley to Macclesfleld were largely the result of George Pearson's conversion to Methodism in 1746. Having walked to Manchester to see him, Pearson invited Wesley to preach outside his house on Waters Green in 1747. Thereafter, the tailor (later a silk manufacturer) became a class leader, and was often host to Wesley on his visits to the

\footnotetext{
${ }^{11}$ B.E. Harris, ed., Victoria history of the counties of England: A history of the county of Chester, volume 3 (Oxford, 1980), p. 109.

${ }^{12}$ Davies, History of Macclesfield, p. 329.
} 
town. ${ }^{13}$ A house in Higher Hurdsfield had been used for religious services in the 1740s and the first official meeting place in Macclesfield was a cottage, rented by Pearson and Elizabeth Clulow, from about $1750 .{ }^{14}$ In the 1760 s the Methodists moved to a building on Buxton Road, but increasing numbers meant that a further move was inevitable. John Ryle gave a site near the Town Yard and this new meeting house sufficed for a further 14 years, when plans were made for a permanent chapel. Ryle donated land on Sunderland Street and contributed towards the building costs. John Wesley preached at the opening of the chapel in March 1780 and it served the community until 1798 when a tragic accident occurred. Overcrowding at a service caused congregation members to believe that the gallery and roof were going to collapse and, in the panic that ensued, six people were killed, many were injured and considerable damage was caused to the building. The trustees acted quickly and complete rebuilding took place in 1799 , doubling the size of the chapel. ${ }^{15}$

After Wesley's death in 1791, the separation of different branches of Methodism had some effect on the denomination, but it continued to expand until the 1830s. In 1801, the combined membership of the Wesleyans and Methodist New Connexion in Macclesfield amounted to $5.1 \%$ of the population, compared to $3.7 \%$ in Congleton and $1.9 \%$ in Stockport. ${ }^{16}$ The strength of this support meant that Macclesfield was made head of a Wesleyan district in 1814, which had nine circuits and 22 preachers. ${ }^{17}$ Sunderland Street chapel was also responsible for the foundation of other Wesleyan institutions in Macclesfield, including three chapels, two schools and a mission hall and many of its members were heavily involved with the nondenominational Macclesfield Sunday school. In 1851, Sunderland Street chapel had an estimated congregation of 1,007 for its two services on census Sunday, and remained the leading Methodist institution in Macclesfield until the twentieth century. ${ }^{18}$ A renovation programme costing £1,500 took place in 1902 and the buildings then remained largely unchanged until the chapel's closure in $1969 .^{19}$

Sunderland Street chapel therefore acted as a focal point for the Methodist community in Macclesfield in the eighteenth century and became the 'mother church' for

\footnotetext{
${ }^{13}$ G. Malmgreen, Silk town: Industry and culture in Macclesfield, 1750-1835 (Hull, 1985), p. 145.

${ }^{14}$ Chester and Cheshire Archives, EMS 6/7/1, Sunderland street chapel trustees minutes, 29 January 1881.

${ }^{15}$ Chester and Cheshire Archives, EMS 6/10/9, Macclesfield Methodism, centenary of Sunderland street chapel, newscutting from Methodist Recorder, 1899.

${ }^{16}$ E.A. Rose, 'Methodism in Cheshire to 1800', Transactions of the historic society of Lancashire and Cheshire, 78 (1975), p. 34.

${ }^{17}$ B. Smith, Methodism in Macclesfield (Macclesfield, 1875), p. 294.

${ }^{18}$ Chester and Cheshire Archives, MF 11/1, census of religious worship, 1851, enumerators' returns for Macclesfield.

${ }^{19}$ Chester and Cheshire Archives, EMS 6/7/2, Sunderland Street chapel trustees' minutes, 23 May 1902.
} 
Wesleyans in the nineteenth. ${ }^{20}$ It offered an alternative structure and social hierarchy to the Anglican church with fewer barriers to the working class. As a result, many of the earlier members were those of more modest background, such as George Pearson, who was unable to sign his name on the chapel's trust deed. However, the opportunities for self-improvement and the Methodist emphasis on diligence meant that many members were able to rise through the ranks and gain respectability. For example, John Wesley, visiting Sunderland Street chapel in 1787, found 'a people still alive to God in spite of swiftly-increasing riches' and warned them against losing their faith. ${ }^{21}$ Even at the end of the eighteenth century, the chapel had five aldermen as seat-holders, showing how it catered for an increasingly affluent congregation. $^{22}$

The chapel was fortunate to have wealthy members who could donate land, property and money. John Ryle was the main benefactor in the chapel's early history, having given two plots of land, money for building costs and $£ 1,000$ to finance the rebuilding in $1799 .^{23}$ Thomas Alien was another silk manufacturer to support the chapel financially through donations, a series of loans and the bequest of a house for the minister. ${ }^{24}$ Subscriptions formed the basis of any major fundraising efforts, supplemented by events such as collections at sermons, tea parties and bazaars. For example, the combined denominational bazaar in 1894 yielded $£ 662$ and the collection at a special service in 1882 raised $£ 210 .^{25}$ When these contributions were insufficient, loans were the next source of income. Weekly class money and pew rents covered most of the general running costs and the latter amounted to $£ 120$ annually in the 1790 s, doubling by the 1820 s. $^{26}$

There were a number of people who were prominent in the chapel's history. In the early stages, George Pearson and Elizabeth Clulow (a baker's wife) were instrumental in securing a place for worship. Pearson remained in the society for 60 years and was still taking two classes a week at the time of his death. He was described as 'unremitting in attentions to the sick and poor' and manifesting 'much generosity in relieving the needy'. ${ }^{27}$ The first John Ryle's contributions were commemorated on a tablet in the chapel as 'a monument of his piety towards God, his love to man and his zeal for the Gospel of

\footnotetext{
${ }^{20}$ Malmgreen, Silk town, p. 146.

${ }^{21}$ Ibid.

${ }^{22}$ Smith, Methodism in Macclesfield, p. 232.

${ }^{23}$ A walk through the public institutions of Macclesfield (Macclesfield, 1888), p. 181.

${ }^{24}$ Smith, Methodism in Macclesfield, p. 242.

${ }^{25}$ Chester and Cheshire Archives, EMS 6/7/1, Sunderland Street chapel trustees' minutes, March 1894; EMS 6/8/4, Sunderland Street chapel trust treasurers' accounts, 1882.

${ }^{26}$ Malmgreen, Silk town, p. 146.

${ }^{27}$ Smith, Methodism in Macclesfield, p. 252.
} 
Christ'. ${ }^{28}$ He also enhanced the respectability of Methodism by becoming the first Methodist mayor in the town and was openly accompanied by John Wesley in the traditional procession to St Michael's church on Easter Sunday in $1774 .^{29}$

Silk manufacturers were generally well represented in chapel affairs, making up five out of seven trustees on the 1779 trust deed. ${ }^{30}$ In addition to his financial assistance, Thomas Alien acted as a preacher from 1796 until his death in 1852 and was a trustee, treasurer and chapel keeper. He was described as 'diligent' and 'faithful' as well as being 'one of the most generous donors' to the cause. ${ }^{31}$ In the latter half of the nineteenth century, John B. Smallwood was 'a staunch supporter of this Chapel', held the position of trustee for 22 years, was secretary for 26 years and was still treasurer at the time of his death. ${ }^{32}$ He and J.B. Lees were also the leading contributors to the 1882 alteration fund, each giving $£ 120$. $^{33}$ However, there were other important members of the Macclesfield society who were not associated with silk, such as Joshua Thorley. He was a poor widow's boy who became a wealthy grocer and acted as a class leader, circuit steward, trustee and Sunday school superintendent. Others included John Birchenall, a cotton manufacturer, and Elizabeth Clulow, who was one of the founder members. ${ }^{34}$

The early motives for involvement with Sunderland Street chapel related to the inspiration of John Wesley during his Cheshire visits and, with this impetus, the early members were able to establish the nucleus of the Macclesfield Wesleyan congregation. However, members had to face persecution from people who saw the new sect as a threat; ladies worshipping at the chapel often had strong mineral acid thrown at their skirts and George Pearson was 'beset by disruptive mobs' who damaged his house windows and threatened arson. ${ }^{35}$ John Ryle also 'lived through the slights passed upon him by reason of his connections with the Wesleyans' and the building of the 1764 meeting house was disrupted. However, Pearson and Ryle persevered and the opposition gradually lessened as the Wesleyans became more established. ${ }^{36}$ The gifts of John Ryle reflected both his increasing fortune and his support for the movement. His daughter is said to have been

\footnotetext{
${ }^{28}$ Macclesfield Silk Museum, 'Mayors of Macclesfield, 1766-1810' (unpublished paper), pp. 28-29.

${ }^{29}$ Chester and Cheshire Archives, EMS 6/7/1, Sunderland Street chapel trustees' minutes, 29 January 1881

${ }^{30}$ A walk, p. 181.

${ }^{31}$ Chester and Cheshire Archives, EMS 6/7/1, Sunderland Street chapel trustees' minutes, 14 June 1852.

${ }^{32}$ Chester and Cheshire Archives, EMS 6/7/2, Sunderland Street chapel trustees' minutes, 5 July 1904.

${ }^{33}$ Chester and Cheshire Archives, EMS 6/8/4, Sunderland Street chapel trust treasurers' accounts, subscriptions towards 1882 alterations.

${ }^{34}$ Smith, Methodism in Macclesfield, p. 243.

${ }^{35}$ Malmgreen, Silk town, p. 145.

${ }^{36}$ Chester and Cheshire Archives, EMS 6/7/1 Sunderland Street chapel trustees' minutes, 29 January 1881.
} 
behind his decision to give $£ 1,000$ in 1799 , saying 'It will only be deducting a quota from each of our fortunes, and I will willingly give mine'. ${ }^{37}$ This was quite poignant as she died shordy afterwards. However, the seriousness of the accident in 1798 was probably the main catalyst for enlargement, as work commenced within a month. The chapel's increasingly wealthy congregation also offered Wesleyans the opportunity to mix with people in positions of power in the town. All these factors could have played a part in encouraging the membership and support of Sunderland Street chapel to varying degrees.

The chapel did experience a period of financial difficulty towards the middle of the nineteenth century as the secession of other Methodist groups took its toll on congregation numbers. As a result, the need to let empty pews in the gallery in 1848 was prioritised and, because of the 'peculiar circumstances of the trust at present', the organist was asked to continue without remuneration over a five year period. ${ }^{38}$ In 1857 , the debt on the chapel stood at $£ 400$ and this money was still outstanding in $1880 .{ }^{39}$ Income from seat rents had also fallen back to eighteenth-century levels at this time, all of which indicates a relative decline in the popularity of the chapel. ${ }^{40}$

Despite these problems, Sunderland Street chapel did manage to achieve much over its history. According to the Methodist Recorder, 'Few Methodist Societies in England can rejoice in such a rich historic heritage as that of Sunderland Street Macclesfield'. ${ }^{41}$ As the first Methodist chapel in Macclesfleld, it was a key institution which acted a place of worship for over 180 years and its congregations included a number of respected and powerful citizens.

Silk manufacturers, such as the Ryles and Pearsons, were the original driving forces behind the establishment of Sunderland Street chapel and there were many others who were influential throughout its history. The reasons for their actions appeared to have been primarily religious in nature, along with other possible subsidiary considerations. Therefore, silk manufacturers were strongly represented in the history of this chapel, particularly during the late eighteenth and early nineteenth centuries.

Having seen how one Macclesfield religious institution was affected by the silk

\footnotetext{
${ }^{37}$ Chester and Cheshire Archives, EMS 6/10/9, Macclesfield Methodism, centenary of Sunderland Street chapel, newscutting.

${ }^{38}$ Chester and Cheshire Archives, EMS 6/7/1, Sunderland Street chapel trustees' minutes, 5 July 1848, 7 February 1853.

${ }^{39}$ Ibid., 13 February 1857, 14 January 1880.

${ }^{40}$ Ibid., 4 February 1898.

${ }^{41}$ Chester and Cheshire Archives, EMS 6/10/9, Macclesfield Methodism, centenary of Sunderland Street chapel, newscutting.
} 
manufacturers, the next example is the nineteenth-century ragged and industrial school.

\section{Ragged and industrial school}

This school was founded by Revd Henry Briant, of St Paul's church, in 1858 and provided education for vagrant or neglected children in Macclesfield. The ragged school movement began in Portsmouth in the 1840s to address the problem of educating the poorest of children. In 1844, a ragged school union was formed (of which Lord Ashley was president) to oversee the schools and by the 1850 s over 100 were in existence. ${ }^{42}$ In Macclesfield $\mathrm{Mr}$ Briant, assisted by members of his congregation, gathered together a group of around 100 children and provided daily instruction and nourishment in an old wheelwright's shop in Turnock Street. After a fundraising effort, the adjoining pigsties were converted into workshops and industrial training was offered to those over eight years of age. ${ }^{43}$

The Industrial Schools Act of 1865 meant that state funding became available for schools meeting the minimum standards, to cover half of the rent and staff salaries and a third of the books and materials. ${ }^{44}$ The committee decided to construct new buildings to gain eligibility for these grants and £2,600 was raised towards the project. The new premises on Brook Street opened as a national industrial school in 1866 and offered residential facilities for the first time. From 1868, the institution offered places for pupils from as far away as Liverpool, Birmingham and London, while 40 beds were retained for Cheshire children. ${ }^{45}$ The implementation of the 1870 Education Act meant that measures were taken to provide elementary education for all children and this started to encroach on the work of the industrial schools. All except 12 institutions had closed by the First World War and only one survived through to $1939 .{ }^{46}$ As the Macclesfield school continued until 1922, it was a comparatively late survivor and the revenue from its building sale was distributed between local charities. ${ }^{47}$

Initially the school opened on four evenings a week and by the end of the first year had 120 children on the books, 14 of whom were orphaned and 48 had one parent. A day school opened in 1859 and had 65 pupils by the end of the year, while a male adult class met

\footnotetext{
${ }^{42}$ I. Bradley, The call to seriousness: The evangelical impact on the Victorians (London, 1976), p. 46.

${ }^{43}$ Davies, History of Macclesfield, p. 271.

${ }^{44}$ H.W. Schupf, 'Education for the neglected: Ragged schools in nineteenth-century England', History of education quarterly, summer edn (1972), p. 174.

45 Davies, History of Macclesfield, p. 273.

${ }^{46}$ Schupf, 'Education for the neglected', p. 174.

${ }^{47}$ The National Archives, ED 49/671, elementary education endowment file, Macclesfield industrial school fund.
} 
on three nights a week. Other associated activities were a Sunday bible class, home visits, mothers' classes and weekly prayer meetings. In 1865, a total of 744 children had received instruction at the school, which consisted of training in trades, such as shoemaking and sewing, supplemented by basic elementary education and religious instruction. ${ }^{48}$ Girls were excluded from the school in 1870, at the request of the government inspector, and the facilities were extended in subsequent years to increase the accommodation. ${ }^{49}$ Later innovations were a gymnasium, swimming pool, sports clubs, a brass band, a fire brigade and cadet corps. ${ }^{50}$ In 1899, the number of pupils stood at 152 and it had gained a reputation for being an 'admirable school'. ${ }^{51}$

In terms of finance, the school was fortunate that the grammar school governors granted the land for their building free of charge, together with additional plots when expansion became necessary. The cost of the Brook Street building was raised from a combination of fundraising events and private donations. The Marquess of Westminster, after an anonymous visit in 1864, sent a letter with a cheque for $£ 500$ asking the managers to accept it 'if they thought they could do any good with it'. ${ }^{52}$ This sum formed the core of the building fund, together with a later donation of $£ 400$ from the same source. ${ }^{53}$ Events such as the oddfellows' fete and musical concerts supplemented the subscriptions and a grant of $£ 600$ was received from the county rate. ${ }^{54}$ In 1889 , the income consisted of £2,355 from the Treasury and School Boards outside Cheshire, £74 subscriptions, $£ 1,574$ industrial and sundry receipts and $£ 350$ from the quarter sessions towards alterations, showing how the institution had moved from voluntary contributions to receiving most of its income from public funds. ${ }^{55}$ But townspeople were still expected to support the institution and a plea for additional funds in 1900 cited changes in the curriculum, Home Office demands and building modifications as the reasons why they found 'it more difficult every year to keep on the right side'. ${ }^{56}$

The initiator of the Macclesfleld school was Mr Briant, who also acted as honorary secretary until 1883 and ensured that it became a successful institution.

\footnotetext{
${ }^{48}$ Chester and Cheshire Archives, D 5299, J.O. Nicholson, 'Macclesfield past', (prize essay for the useful knowledge society, 1866), p. 79.

${ }^{49}$ Macclesfield Courier and Herald, 12 May 1900, p. 6.

${ }^{50}$ A walk, p. 27.

${ }^{51}$ Macclesfield Courier and Herald, 19 March 1897, supplement.

52 Ibid., 12 May 1900, p. 6.

${ }^{53}$ Chester and Cheshire Archives, SL 77/1/1, Macclesfield industrial school minutes, 12 December 1864.

${ }^{54}$ Davies, History of Macclesfleld, p. 272.

${ }_{55}$ Macclesfield Courier and Herald, 13 April 1889, p. 6.

${ }^{56}$ Ibid., 12 May 1900, p. 6.
} 
Among the congregation members who assisted the vicar was $\mathrm{Mr} H$ eap, a local businessman, who became the manager of the school. He and his wife then ran the institution for over 40 years, which was a significant undertaking. In 1899, the committee acknowledged the couple's contribution, stating that 'unstinted praise is due for the ability and devotion which has marked their career', and a newspaper article in 1900 concluded that 'Mr Heap had in the school a life's work of which any man might feel proud'. ${ }^{57}$

Other important contributors were the marquesses, later dukes, of Westminster, who became president of the institution, and members of the Brocklehurst family. Charles Brocklehurst gave between $£ 700$ and $£ 800$ during his lifetime and acted as chairman, Fanny Brocklehurst arranged fundraising events, P.P. and W.C. Brocklehurst each gave $£ 100$, and F.D. Brocklehurst acted as treasurer, leaving a legacy of $£ 1,000$ in 1905 . $^{58}$ In addition, F.D. Brocklehurst and W.W. Brocklehurst donated a fire engine for the fire brigade and various family members paid for the Christmas treat. ${ }^{59}$ Other silk manufacturers were also involved, such as William Barnett, J.B. Wadsworth, George Heath and James Kershaw, who gave their money and time for the institution. However, there were other key people who were active in the school, such as John May (a solicitor) who acted as vice-president for over 30 years. ${ }^{60}$ This mixture is illustrated by the trustee list for 1893 which features clergymen, such as Revd W. Sinden and John Thornycroft (the rural dean), representatives of county families, such as the Duke of Westminster and Lord Egerton of Tatton, along with a range of Macclesfield people including Thomas Crew (a silk manufacturer), W.B. Staghall (china shop proprietor) and William Mair (solicitor). ${ }^{61}$

The ragged and industrial school was originally founded by Anglican church members and religious instruction was an important part of the curriculum. As a result, the evangelical belief in feeding and clothing the poor, as a precursor to the potential conversion of souls, is likely to have been one of the main motivational factors for initial involvement with the institution. ${ }^{62}$ Some of the many reasons which prompted supporters are revealed by the annual reports, which were always keen to emphasise how their money meant that the poorest children were saved from a potentially degenerate life and could

\footnotetext{
${ }^{57}$ Ibid., 25 February 1899, p. 2; 12 May 1900, p. 6.

${ }^{58}$ Ibid., 12 May 1900, p. 6; Chester and Cheshire Archives, SL 77/1/1, Macclesfield industrial school minutes, 22

December 1880; 1 May 1861; A walk, p. 27; Macclesfield Courier and Herald, 11 November 1905, p. 5.

${ }^{59}$ Chester and Cheshire Archives, SL 77/1/1, Macclesfield industrial school minutes, 20 October 1890.

${ }^{60}$ Macclesfield Courier and Herald, 3 December 1904, p. 3; Chester and Cheshire Archives, SL 77/1/2,

Macclesfield industrial school minutes, 24 May 1895.

${ }^{61}$ Ibid. 18 February 1893, p. 6.

${ }^{62}$ Bradley, The call to seriousness, p. 44.
} 
obtain employment as a result of their educational experience. For example in 1869, the managers stated that the

...original intention of the Ragged School when founded, is steadily kept in view, namely - the taking off from the streets those children who, brought up to begging and worse, or without home and under no proper control, would never care but to appear in filthy rags, nor would ever be likely to learn those moral and religious duties essential to their own and others well being, but eventually become criminals. ${ }^{63}$

It therefore appealed to subscribers and donors as a particularly worthy cause which addressed the difficult problem of educating vagrant children (who were not welcomed in elementary schools). The fact that most pupils were able to support themselves on leaving the institution was important for Macclesfield citizens, whose tax burden was adversely affected by any increase in the number of people receiving poor relief. Some of the children were able to find work in the silk mills and so the manufacturers benefited indirectly from their skills, while any reduction in the crime rate would have been attractive to owners of property. The participation of leading figures, such as the marquess or duke of Westminster, may also have added respectability to the institution and encouraged people to subscribe, particularly in the early days of its history. Consequently, there were a number of reasons which could have prompted the support of the silk manufacturers for the institution.

The rosy picture of the school portrayed in the annual reports was not always the whole story and there is the occasional inclusion of less favourable results. Inevitably, there were some children who did not capitalise on the opportunities and reverted to a life of crime. For example, of the 82 boys discharged in 1887, five were recorded as convicted and another two were 'doubtful'. ${ }^{64}$ Another indication of the failure rate is that between 1869 and $1871,91 \%$ of boys and $80 \%$ of girls were reported as doing well and of the 50 discharged, 36 were in jobs directly related to the training they had received. ${ }^{65}$ However, the bulk of the evidence points towards the positive benefits of the institution for pupils. For example, Mr D. Bradwell, (manager of Brocklehurst's C Mill) stated that 'Many of the Ragged School scholars rank among the best hands, some have continued

\footnotetext{
${ }^{63}$ Macclesfield Courier and Herald, 6 March 1869, p. 5.

${ }^{64}$ Ibid., 13 April 1889, p. 6.

65 Ibid., 4 January 1873, p. 5.
} 
four, five and six years in the mill'. Former pupils who called into the school to thank the master for their education were mentioned in the annual reports, such as one who was filling an important position in Stockport and another who was working for a publisher in Liverpool. ${ }^{66}$ The inspectors also gave the institution praise and in 1877 the visiting H.M.I, stated that 'I was particularly pleased with the workshops, I know of no school where industrial training is carried on more judiciously, or with greater success or with more practical results'. ${ }^{67}$

The school thus became a well respected institution during the nineteenth century, to the extent that it had a constant stream of visitors keen to gain an insight into how such a school should be run. There is clear evidence of ongoing financial and managerial support from the silk manufacturers and their public motives appear to have been primarily religious and altruistic in nature. However, the wide range of dedicated people needed to run such an institution, particularly the key contribution made by $\mathrm{Mr}$ Briant and Mr and Mrs Heap, means that their involvement was an integral part of the school's broader support base.

These two examples, founded in the eighteenth and nineteenth centuries, illustrate the ways in which the silk manufacturers were able to support the development of institutions through their personal involvement, financial contributions and managerial support. Sunderland Street chapel exhibited a particularly strong influence in the early phases of its development and the ragged and industrial school showed how their dominance was reduced somewhat by other important individuals. The obvious reasons underlying their actions in these instances appear to have been related to their religious beliefs and altruism. However, these represent only two religious institutions out of the 78 voluntary organisations in the town and it is important to consider the entrepreneurs' contributions across the whole range. As a result, the next section will give a broad overview of their involvement with Macclesfield's institutions.

\section{The silk manufacturers and their support of Macclesfield's voluntary institutions}

In order to gain an idea of the range of affiliations for the silk manufacturers, a comparison has been made from all the extant records. This analysis revealed that there was a core of

\footnotetext{
${ }^{66}$ Ibid., 6 March 1869, p. 5.

${ }^{67}$ A walk, p. 27.
} 
people who supported many different foundations. There were 21 silk manufacturers (or their family members) who were associated with ten or more charities and six of these were members of the Brocklehurst family. William Coare Brocklehurst was the only person with 16 causes, his father John supported 15, while William Barnett, P.P. Brocklehurst and John Birchenough followed with 14 charities. The range of institutions supported was dependent on their individual beliefs and interests. For example, T.U. Brocklehurst had links to 13 charities across all the categories, whereas David Holland supported 11 religious causes and one public service institution.

The type of involvement varied from occasional subscriptions to dedicated service over long periods of time, such as James Jackson's 54-year superintendence of the Lord Street Sunday school. ${ }^{68}$ In some organisations, such as King Edward Street chapel, these businessmen were able to assert almost complete authority and in most others they were still influential. Generally, the number of silk manufacturers involved declined towards the end of the nineteenth century as the industry contracted. For example, at Park Street Methodist New Connexion chapel, five out of six trustees were silk manufacturers in 1836, but in 1901 there were only two left out of $13 .^{69}$ My figures are likely to be an underestimate of the number of charities supported by individuals because of factors such as missing or incomplete records and anonymous donations. Most manufacturers would also have contributed to other non-Macclesfield charities and some of the causes that had appeals in the Courier and herald were the R.S.P.C.A. and relief funds in other areas.

The only non-silk individual to support ten or more institutions was John May, who was behind many of the improvements in Macclesfield and aided 12. He spearheaded the campaign for sanitary reform and was heavily involved in the establishment of the baths and washhouses, West Park and the infirmary. His contribution was described in his obituary as follows: 'he was an energetic, intelligent, honourable, and incessant worker in every cause that would tend to promote the welfare of the town he loved so well'. ${ }^{70}$ The only outright donation by a non-silk manufacturer was the public library given by David Chadwick (an accountant and later a cotton manufacturer) who assisted a total of six causes. Other supporters of multiple establishments included William Bromley Davenport who aided eight, the Duke of Westminster with six and Revd Joseph Freeston five. These

\footnotetext{
${ }^{68}$ Macclesfield Courier and Herald, 22 August 1874, p. 5.

${ }^{69}$ Chester and Cheshire Archives, EMC 1/14, Macclesfield Methodist New Connexion circuit, minutes of quarterly meetings, 5 June 1836; EMS 5/4648/1, Park Street Methodist New Connexion chapel, Macclesfield, trustees' minute book, 29 August 1901.

${ }^{70}$ Macclesfield Courier and Herald, 3 December 1904, p. 2.
} 
people were joined by representatives from a mixture of backgrounds such as innkeepers, shopkeepers, physicians and managerial staff from the mills. As a result, a wide crosssection of people played their part in the development of these organisations.

However, even the well-respected John May had to seek assistance from the silk manufacturers in order to achieve his goals. All the available evidence suggests that this group (and especially the Brocklehursts) were highly prominent in the development of Macclesfield's charitable organisations as part of their role in the town's elite. The fact that they did not contribute to all was probably realistic, given the number of causes clamouring for their money and time. Therefore, the surviving records confirm that these industrialists were heavily involved in financing and organising the responses to Macclesfield's problems throughout the period.

And now we move on to the awkward question of motive. It is difficult to get a true idea of why the silk manufacturers supported charities and these conclusions have been drawn from the available evidence in Macclesfield. Altruism was the most frequently cited reason and is likely to have influenced most silk manufacturers to a degree. For example, Joseph Tunnicliffe's professed reason for the infirmary endowment was to meet the needs of the 'deserving sick and infirm poor'. ${ }^{71}$ Promoters usually expressed the hope that new institutions would effect real change within the town and F.D. Brocklehurst's comments at the opening of Victoria Park were an obvious example. He said that the Hurdsfield area suffered from 'the somewhat depressing dullness and monotony of its surroundings' and hoped that his gift would 'provide a lasting source of pleasure both active and restful to the inhabitants of this part of the town'. ${ }^{72}$

Religion was another strong motive, as the two case studies have illustrated, and religious leaders were important in encouraging individuals to assist the poor. As a result, most annual reports emphasised the Christian duty of citizens to support these organisations, whether religious or secular. For example, the useful knowledge society's annual report in 1843 stated that religion 'bids us to live - to practise, to adorn, and to enjoy it - to breathe around us a spirit of charity and love - to obey its perfect precepts, and to exemplify in our whole lives the purifying efficacy of its doctrines'. ${ }^{73}$ In general,

\footnotetext{
${ }^{71}$ Chester and Cheshire Archives, LBM 2703/45/2, Macclesfield borough council, general purpose committee minutes (within water committee minute book), 12 May 1859.

${ }_{72}$ Macclesfield Silk Museum, record of the proceedings at the opening of the new Victoria Park, 14 May 1894, p. 27.

${ }^{73}$ Chester and Cheshire Archives, D 4908/2, Macclesfield society for acquiring useful knowledge, annual reports, 1843, p. 8.
} 
Macclesfield's silk manufacturers tended to support charities across denominational divisions and appeared to be more concerned with their associated advantages for the town.

There were a number of more self-interested reasons that could also have been important and the most apparent were the advantages for employers. Many silk manufacturers aimed to exert a paternalistic influence on their workers to gain loyalty and respect. As a result, businessmen supporting institutions of direct benefit to their employees, such as the dispensary and West Park, may have gained some respect for their actions. However, there were times when criticism was levelled at the silk manufacturers for their charitable activities. For example, T.U. Brocklehurst's donation of overcoats for cabmen in 1879 caused an angry reaction from the company's weavers, who were facing extreme hardship and felt aggrieved that his gift had not been directed towards them. ${ }^{74}$ Macclesfield's reliance on a luxury fabric meant that full employment was rarely possible and long lay-offs caused many workers to descend into poverty. In this context, manufacturers' efforts to provide facilities, particularly the ones that that were not well attended and were believed to benefit employers, might have been perceived as a poor substitute for a guaranteed wage.

Institutions which benefited employers included educational organisations, such as Sunday schools, which provided disciplined factory workers. The dispensary, infirmary, baths and public parks were all facilities that could improve the health of their workers and prevent the spread of disease, while the dispensary and infirmary provided a costeffective way of dealing with factory accidents. Support for the relief association provided sustenance for the unemployed during trade depressions and may have prevented skilled workers from leaving Macclesfield. Thus, these initiatives were all well supported by silk manufacturers.

As many entrepreneurs were social leaders, charitable involvement was an essential part of their public persona. These organisations offered the opportunity to meet influential people and those with political ambitions could show their suitability for public office through service on institutional committees. Philanthropic gifts also marked periods of public service and enhanced the reputations of particular families; obvious examples were James Kershaw's donation of a fountain to commemorate his mayoral

\footnotetext{
${ }^{74}$ Chester and Cheshire Archives, LBM 2703/62/1, Macclesfield Borough Council, newscuttings, 18 January 1879, p. 38.
} 
year and the gifts of Victoria Park and West Park museum from the Brocklehurst family. The middle-class duty to participate in public life was another obvious motivating factor and John Brocklehurst refused a baronetcy three times, reportedly 'desiring no other satisfaction than to do his duty'. ${ }^{75}$ Some manufacturers specified that they wanted do something positive for the community that had helped to make their fortune and Joseph Tunnicliffe's infirmary endowment was a clear example. The building of Christ Church was a visible statement by Charles Roe about his Anglican faith and his personal respectability. His determination that the tower should be higher than St Michael's church was a deliberate challenge to the older institution's religious supremacy and made Christ Church a permanent reminder of Roe's business achievements.

These institutions also offered a number of advantages to those involved in municipal affairs. They encouraged a sense of pride in a rapidly changing community and united people towards a common purpose. This was shown by the opening ceremonies for new institutions, which involved a programme of celebrations for the whole town. Many organisations were seen to be beneficial in the preservation of public order, particularly in the 1840s with heightened concern about unrest and revolution. In Macclesfield this was apparent in the foundation of St Peter's and St Paul's churches (and their associated institutions) on the common, which was a centre for Chartist activity. Therefore, the high number of institutions founded at this time was an indication of the danger felt by Macclesfield inhabitants. The silk manufacturers' multiple roles as public leaders, employers and magistrates meant that they could see the correlation between the lack of educational opportunity and crime. For example, in 1878 T.U. Brocklehurst said at the opening of St Peter's working men's institute that:

His experience on the Bench as a magistrate gave him an idea of what was required for the elevation of some sections of the working class; many cases came before them, in which of course they were bound to administer the law, but which it was evident had arisen from simple ignorance and want of cultivation. ${ }^{76}$

New facilities enhanced the town's status within the local area and underlined its

\footnotetext{
${ }^{75}$ Macclesfield Public Library, How loyal Macclesfield and the district celebrated the diamond jubilee of Queen Victoria (Macclesfield, 1897), p. 10.

${ }^{76}$ Chester and Cheshire Archives, P 187/8/4, St Peter's working men's institute, reprint from Macclesfield Courier and Herald on laying the foundation stone, 1878, unpaginated.
} 
reputation as a progressive industrial settlement. The establishment of voluntary institutions within the community was also seen by most town leaders as preferable to state initiatives. They thought that local knowledge was paramount and feared government intervention, often because it meant an increase in taxation. The prime example was the opposition of certain silk manufacturers (led by John Brocklehurst) to the 1847 Improvement Act, for water, gas and sanitary improvements, which delayed progress for four years. ${ }^{77}$ As a result, the silk manufacturers' motivation in supporting charitable institutions is likely to have been affected considerably by a range of local and national circumstances. Their public assertions showed the general desire to improve Macclesfield and the welfare of its inhabitants, but there were many other factors that could have been contributory.

Turning to the performance of the charitable institutions in Macclesfield during this period, they did exhibit some of the negative characteristics of philanthropy cited by critics, such as wastage of resources. The lack of central coordination led to a disparity in provision, with some areas having many voluntary institutions, while others had few. For example, rival churches and chapels were established close to one another, each with its own range of services. The most obvious example was in northern Sutton, where Anglican, Wesleyan, Methodist New Connexion and Baptist institutions were established in adjoining streets.

The way in which leaders reacted to mass unemployment illustrated the limitations of voluntary action. By the time the relief funds were initiated, families were often starving and the organisation struggled to cope with the numbers of applicants. Home visiting was used to determine whether people needed aid and this system was viewed by many working-class people as intrusive and demeaning. ${ }^{78}$ The Macclesfield relief association committee also acknowledged in 1893 that the provision of aid caused certain people to become dependent instead of finding ways out of poverty for themselves. ${ }^{79}$

The provision of rational recreation for the working classes generally met with litde endiusiasm and pubs remained the main social meeting place. Most working people made full use of the institutions of value to themselves (such as Sunday schools) without accepting the accompanying religious or moral overtones. Financial considerations were important in explaining poor day-school attendance because most children needed to earn money and

\footnotetext{
${ }^{77}$ P. McBride, 'The struggle for sanitary reform in mid-nineteenth-century Macclesfield' (unpublished M.A. assignment, Manchester Metropolitan university, 1997), pp. 71-76.

${ }^{78}$ B. Harrison, Peaceable kingdom: Stability and change in modern Britain (Oxford, 1982), p. 253.

${ }^{79}$ Macclesfield Courier and Herald, 4 March 1893, p. 4.
} 
parents were unable to afford school fees. As a result, the standard of education in Macclesfield was generally low and, even after the enforcement of the 1870 Education Act, the large number of children working on a half-time basis added to the problems. Despite concerted efforts to encourage working people to attend religious worship in the town, over 70 per cent of Macclesfleld's population was absent for the ecclesiastical census in $1851 .^{80}$ The silk manufacturers' expectations that the school of art and technical school would arrest the decline in Macclesfleld's silk trade in the nineteenth century proved to be misplaced. Problems such as attendance and the standard curriculum meant that the gradual improvements in design and technical education were little compensation for the protective measures of the Cobden Treaty, which favoured foreign silk firms after 1860.

Despite these limitations, the charitable initiatives did achieve some notable success. The new facilities were the basis from which the modern system has developed and the fact that many of these organisations still exist today indicates that they met a real need. Particular institutions, such as Christ Church schools and the ragged and industrial school, gained a good reputation, while the medical charities improved the population's health. Some facilities, such as the baths, were so well used that overcrowding was common and some Sunday schools had to turn children away because of the high demand for basic education. $^{81}$

The establishment of voluntary institutions was seen to have a positive effect on law and order, particularly in areas where unrest was a potential problem. The educational institutions offered the chance for self-improvement and there were examples of gratitude from former pupils in the annual reports indicating that their education had stood them in good stead for an industrious life. ${ }^{82}$ There were a number of people who progressed from a humble background to become businessmen themselves and this showed that some were able to capitalise on opportunities to improve their prospects. Organisations like the volunteer force and the volunteer fire brigade also encouraged social interaction between members from differing backgrounds and this did help to break down social barriers.

Thus, in spite of the many difficulties that faced Macclesfield charities, they did develop to meet the various needs of townspeople prior to centrally driven improvements. These innovative organisations brought people together, regardless of class, political

\footnotetext{
${ }^{80}$ K.S. Inglis, Churches and the working classes in Victorian England (London, 1964), p. 1.

${ }^{81}$ Chester and Cheshire Archives, LBM 2703/4/2, Macclesfield Borough Council, baths committee minutes, 16 December 1895; Malgreen, Silk town, p. 154.

${ }^{82}$ Chester and Cheshire Archives, SP 2/31/32, reports of the Macclesfield Sunday school, 1895, p. 1.
} 
persuasion or religious affiliation, to improve life for inhabitants in the town. In particular, progress in the fields of health and education throughout the nineteenth century point towards the positive effects of early voluntary action in Macclesfield, along with later governmental intervention. Similarly, the acquisition of a range of facilities served to raise the town's profile, both locally and nationally, as a leading centre for silk. As a result, Macclesfield's voluntary institutions did manage to achieve much during this period.

In most cases the silk manufacturers were heavily involved in funding and managing these institutions and their obvious motives reflected altruistic, religious and educational beliefs, plus a variety of other reasons which could have been influential. Consequently, a portion of the credit for the achievements of the voluntary institutions in the eighteenth and nineteenth centuries can be attributed directly to the Macclesfield silk manufacturers.

In a wider context, Macclesfield's acquisition of voluntary organisations, the part played by industrialists and their range of motivations were typical of a small to medium sized industrial town where there was considerable scope for leading manufacturers to become involved in all aspects of its development. Other northern towns where there was an overlap of economic, social and leadership roles were Accrington, Ashton, Burnley and Warrington, where a relatively small group of people exercised a disproportionate influence over many areas of town life. ${ }^{83}$ In contrast to the factory villages built by many cotton manufacturers, few Macclesfield manufacturers provided any housing, preferring to leave workers to find their own accommodation. Instead, as we have seen, they opted to assist Macclesfield's voluntary organisations, which gave them freedom to participate in particular fields of interest and offered a range of benefits in return. Therefore, Macclesfield does display many similarities in this field with other northern textile towns, but there were also some local and personal differences which contributed towards the pattern and success of its philanthropic provision.

To conclude, this second extract from Thomas Unett Brocklehurst's obituary illustrates how charitable involvement enhanced his reputation as a responsible businessman and generous benefactor to the town:

Be that as it may, by his death Macclesfield has lost a true friend, and, though the subject of this sketch, had he been consulted in regard to our endeavour to enumerate his many excellent qualities and good deeds, would have been the first

\footnotetext{
${ }^{83}$ A. Russell, 'Local elites and the working-class response in the North-West, 1870-1895: Paternalism and deference reconsidered', Northern history, 33 (1987), p. 156.
} 
to discountenance any such effort, we feel it a public duty to do so - to pay a just though imperfect tribute to a good man, believing, with Bishop, that

To hide true worth from public view, Is burying diamonds in their mine, All is not gold that shines, 'tis true, But all that is gold ought to shine. ${ }^{84}$

${ }^{84}$ Macclesfield Courier and Herald, 21 August 1886, p. 5. 